\title{
The Evaluation of Use of Marketing Communications in Enterprises in the Field of Informal Education in Latvia
}

\author{
Maksim Rapoport \\ Alliance Board of Credo and Autoprieks, Latvia
}

Copyright $(2016$ by authors, all rights reserved. Authors agree that this article remains permanently open access under the terms of the Creative Commons Attribution License 4.0 International License

\begin{abstract}
This article emphasizes the relevance of use of marketing communications for recognition of the enterprise, operating in the field of informal education, the definition of informal education in Latvia is given, the leading enterprises in the market of informal education are distinguished and characterized, these driving schools are AUTOPRIEKS/CREDO, Fortūna, "Real Proff" The results of marketing researches are represented that have established the leadership among driving schools and an assessment of effectiveness of use of marketing communications has given. The represented analysis has defined marketing communications mix, consisting of 6 promotion tools and has found that it is typical, namely, for the field of informal education in Latvia.
\end{abstract}

Keywords Field of Informal Education, Enterprise/Driving School, Marketing Communications, Promotion Tools

\section{Introduction}

Marketing communications are very popular topic among scientists - marketers. A lot of literature is published on this topic, many scientific articles are written. Leading in this topic are American and European scientists - marketers: Kotler, K. Keller [1] N. Kanon; Dzh. Makhalbert [2]; O. Walker [3]; J. Hubert. [4]; V. Praude [5] T. Golubkov [6]; Russian: Golubkov E. N [7] Romanov A. A, A.V Panko [8]; Romanenkova O. N [9]; Sinyaeva I.M, Zemlyak S. Sinyaev V.V [10].

However, the results of the carried out analysis of scientific works of mentioned and other authors allow drawing conclusions that the topic of use of marketing communications, used in enterprises, carrying out their activity in the field of informal education and peculiarities of their use are not highlighted. These circumstances allow filling this gap.

\section{Methods}

For the writing of this paper were studied the different materials in the field of communications at the intersection of interdisciplinary sciences - marketing, sociology, psychology, pedagogy. As a result of analytical approach to the identification of the problem of research and its solution a system of actions has been developed: a) to characterize the informal education in Latvia as an area of enterprises. To identify the main directions of activity of informal education and to characterize the leading enterprises for the comparison and assessment of use of marketing communications in the general mix of promotion of services in the Latvian market;

b) For the assessment of use of marketing communications of the chosen enterprises as an example, to undertake marketing researches. For their carrying out, the methods of collection of information are defined, both desk and field research and methods of research, as observation and survey. For the survey the sample is made up 250 respondents.

\section{The Results of the Research}

The effectiveness of marketing communications with consumers has become a key factor of success of any organization, including the organizations, implementing their activity in the field of informal education. The study of development of the field of informal education in Latvia is of the utmost interest and the study of use of marketing communications in this field is very relevant. In this regard, we will denote the goal of this paper as: the evaluation of use of marketing communications in the enterprises of informal education in Latvia and definition of peculiarities of promotion tools.

\subsection{Informal Education in Latvia}

The informal education in Latvia, along with the formal education is regulated by the Law on education. Formal education it is a system, including levels of basic education, secondary and higher education, acquisition of the program which approves and recognizes the state or document on 
professional qualification. Informal (or out- of - school education) represents any form of organized and systematic activity which can't coincide with the activity of schools, colleges, universities and other establishments, including in the formal systems of education [11]. In other words, informal education it is a subsequent education which first of all follows basic education. The choice of direction of informal education depends on the need, demand, priority and desire of each individual. [12]. to the enterprises, offering service in informal education refers driving school of vehicles. In other words it is driving schools. According to statistics, in Latvia there are 309 enterprises - driving schools and driving courses [13]. For carrying out the research, from the total number of enterprises have been chosen two objects, driving schools in Riga, namely, AUTOPRIEKS/CREDO and Fortūna.

\subsubsection{We will represent the general characteristic of enterprises/driving schools, operating in the field of informal education.}

Autoprieks/Credo is one of the leading enterprises among driving schools in Latvia. Under such name, the enterprise has been working only since the $1^{\text {st }}$ of January, 2015, when two largest Latvian driving schools CREDO and AUTOPRIEKS have united in one structure. Before the unification, each school had a good business history in the market of informal education. In general, for 14 years of work, driving schools have trained more than 25000 trainees, besides in both schools, the average percent of passing of the state exam among trainees has made about $88 \%$. Nevertheless, for the improvement of competitiveness and consolidation of positions in the market, the decision was taken to join commercial efforts. Today, in the staff of new driving school work more than 100 employees. The branches of driving school are not only in Riga, but also in the cities of Latvia: Balozi, Jurmala, Liepaja, Jelgava, Ventspils and Daugavpils. The driving school bears the social responsibility and takes part in all possible events, supporting good initiatives. [13]. With the driving school cooperate: the State Agency of Employment, the airport "Riga", Police College, the National Armed Forces, the Riga society of Samaritans and other state and commercial organizations which trust in professionalism of driving school. [14].

The driving school "Fortūna" was founded in 1994, as well as driving school AUTOPRIEKS/CREDO is one of the leading driving schools of Latvia. In the driving school work experienced trainers and instructors. The school has 12 branches, including in Liepaja, Daugavpils, Jurmala, Bauska and Valka. [13]. "Fortūna" offers training practically on all categories, including the professional one. They train drivers of water, tractor transport, car and electro car, offer courses of extreme driving. Many drivers come to school for obtaining higher qualification [15].
Real Proff. LLC "Real Proff" was established in 2010 on the basis of professional training center of Riga. Traditions put in this educational institution are closely intertwisted with the modern innovations, embodied in qualitative and available training. Driving school actively use discounts for students [16].

\subsection{The Evaluation of Use of Marketing Communications}

From the above presented characteristics, i.e., diversity and attractiveness of provided services by the mentioned enterprises, it can be assumed that for the consumer, the selection of the object for the satisfaction of his/her needs is quite complex process. Under such conditions, namely, marketing communications and its mix, used by the enterprises, help the consumer with the choice of future consumption of service [17]. For obtaining objective information, regarding the use of communications by the organizations in informal education, the marketing research was carried out.

The results of the carried out survey have shown that the most recognizable among respondents is the driving school Autoprieks/Credo, almost $94 \%$ of all respondents have voted for it.

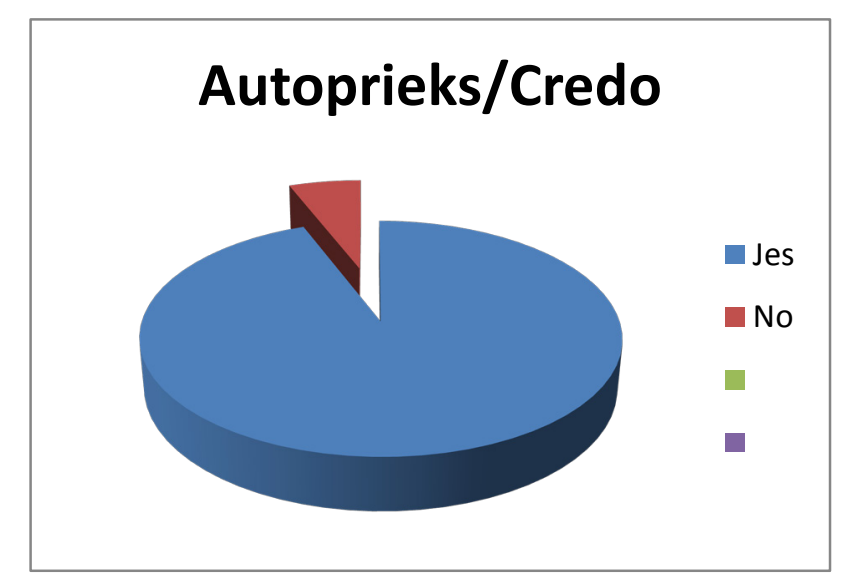

Figure 1. Recognition of the driving school Autoprieks/Credo among consumers

Moreover, the vast majority of respondents have pointed out that they have learned about driving school Autoprieks/Credo from internet $-44 \%$, from their friends and acquaintances $-30 \%$ and as a result of visiting exhibition $-26 \%$. For the driving school "Fortūna", in terms of recognition has voted $58 \%$ of respondents. The majority of respondents have learned about the driving school "Fortūna" on the Internet $-26 \%$ of respondents, from friends, a little less $-18 \%$ and as a result of exhibition $-5 \%$. 


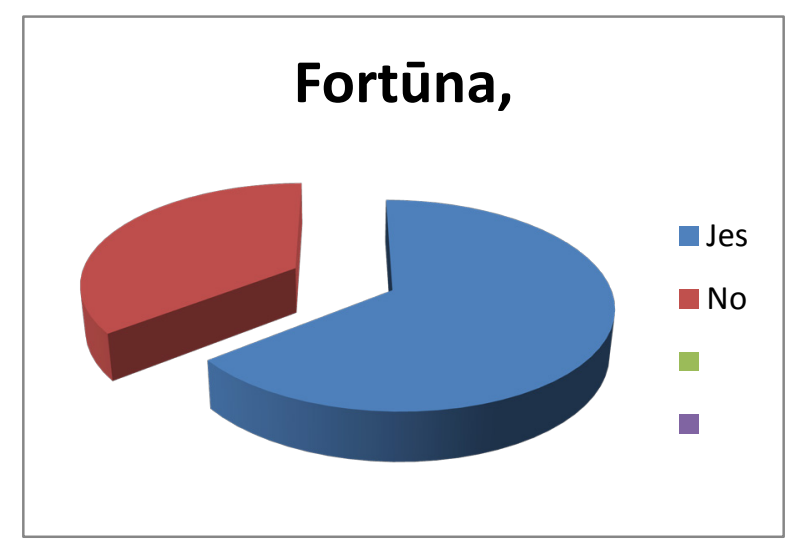

Figure 2. Recognition of the driving school "Fortūna" among respondents

The results of the survey of respondents on the issue of recognition of the driving school "Real Proff" were predictable". The driving school is a little - known among the respondents. We have learned about the school through acquaintances and by the means of Internet. The school didn't participate in exhibitions.

Evaluating the influence of tools of promotion of services on the consumer of the driving school Autoprieks/Credo in Latvia, the highest scores were assigned to the effectiveness of events on sales promotion and advertising. The high estimate to the public relations assigned only $21 \%$ of respondents and the lowest score got the effectiveness of personal sales $7 \%$.

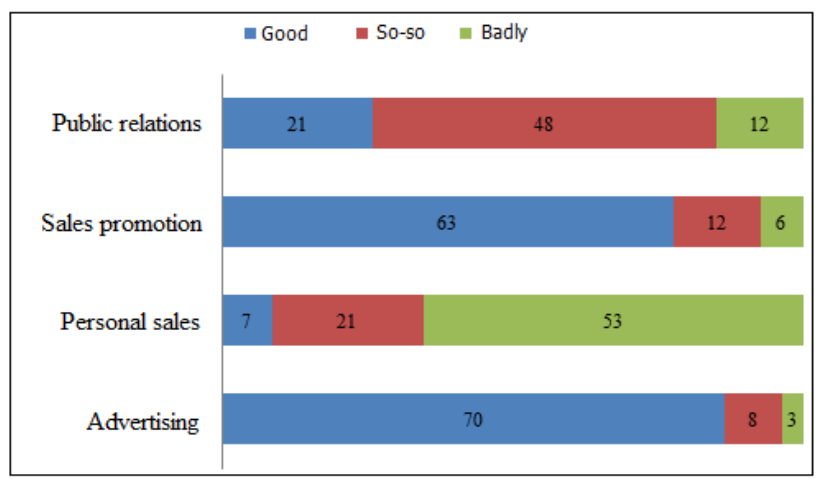

Source: development of authors

Figure 3. The assessment of use of marketing communications tools for the promotion of services of Autoprieks/Credo

In the case of driving school Fortūna the situation looks a little bit differently. For example, the effectivenes of work of public relations, on sales promotion, advertising estimated approximately equally, on an average about $24.7 \%$. The effectiveness of personal sales, as in the previous case with the driving school Autoprieks/Credo, the driving school Fortūna has a very low effectiveness.

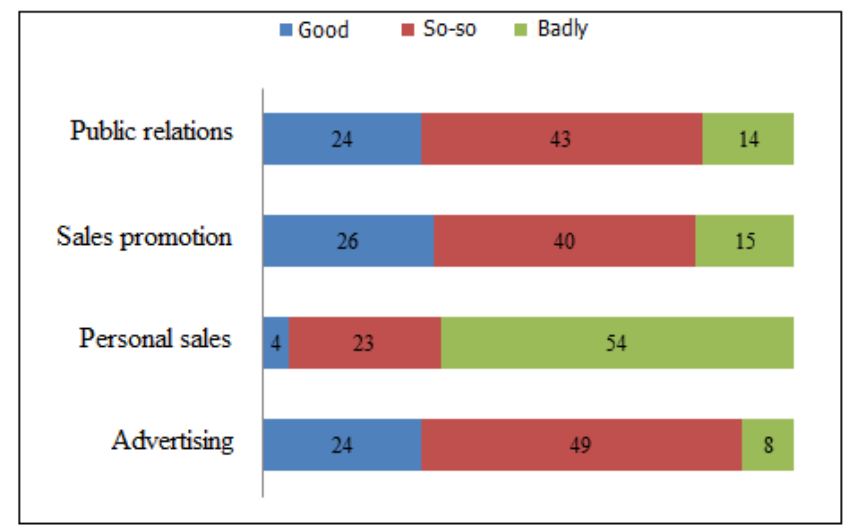

Source: development of authors

Figure 4. The assessment of use of marketing communications tools for the promotion of services of Fortūna

All without the exception tools of marketing communications mix of the driving school Real Proff, the respondents estimated whether satisfactory or bad. The greatest attention the management of the driving school, according to the opinion of respondents should be paid to the issues of effective sales.

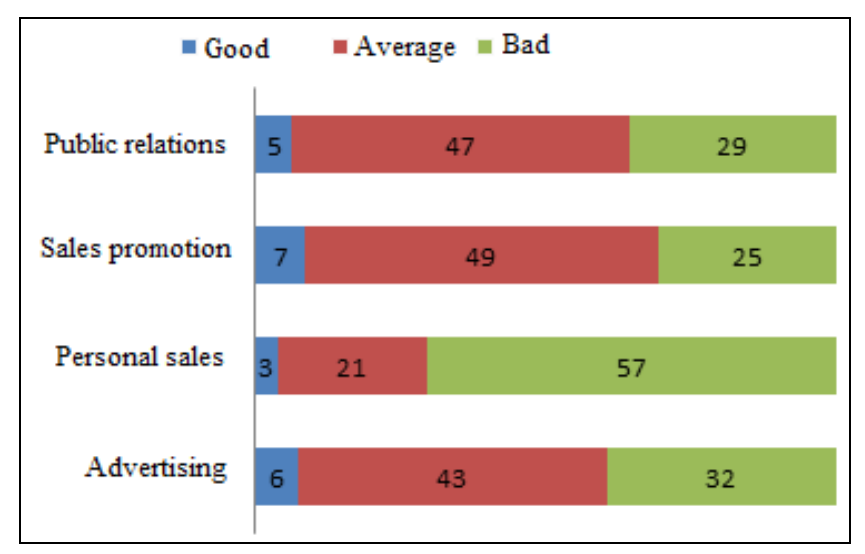

Source: development of authors

Figure 5. The assessment of effectiveness of use of marketing communications for the promotion of services Real Proff

The results of the research for the promotion of this enterprise have proved the hopelessness of development of activity in the market of informal education and preservation of competitiveness along with the enterprises which use the entire marketing communications mix.

Summing up the results of the carried out survey, it may be noted that both enterprises "AUTOPRIEKS/CREDO" and "Fortūna" actively use advertising, sales promotion, PR, but not quite actively, but use direct sales, participate in the annual exhibitions of "Education" and use Internet promotion in its best manifestation - communicating with potential consumers, i.e., use marketing communications mix, including 6 tools of promotion. 


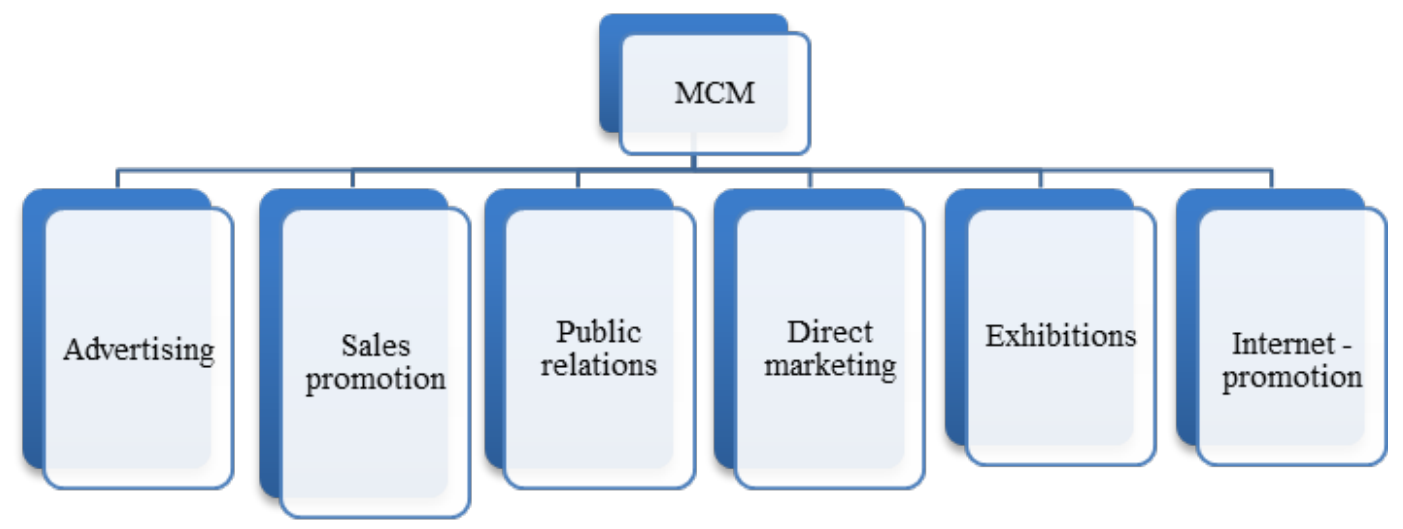

Figure 5. Marketing communications mix of 6 tools of promotion for the enterprises of informal education

In this connection, one may state that the reflected marketing communications mix in the figure 5 is typical for enterprises of informal education and as the recognition of enterprises is great (Figure 1, Figure 2), it is quite effective for the market promotion.

\section{Conclusions}

The carried out research of use of marketing communications has shown that the enterprises, operating in the field of informal education actively use traditional tools of promotion: advertising, PR, sales promotion, direct sales [18]. Along with them, driving schools use Internet promotion and exhibitions. Some tools are used actively, others, such as direct sales not quite actively, however, the effectiveness of their use is obvious. This has shown the analysis of recognition of enterprises among consumers. Moreover, the carried out analysis has allowed revealing the marketing communications mix of 6 tools of promotion, typical for the field of informal education in Latvia.

\section{REFERENCES}

[1] Kotler P. \& Keller K.L Marketing Management (12th ed., trans from eng). St.Peterburg: Piter, 2010.

[2] Kapon N., \& V. Kolchanov, \&J. Makhalbert P. \& Keller K.L. Marketing Management (trans from eng). St.Peterburg: Piter, 2010.

[3] Walker O.C. Marketing strategy: A decision focused approach. - NY.: Palgrave McMillan, 2006.

[4] Hubert J. Total integrated marketing: breaking the bounds of the function. - L.: Kogan Page, Chartered institute of Marketing, 2005.

[5] Praude, Valerijs. Marketing. 1. Gr. - 3. izd. - Rīga: Burtene, 2011.

[6] Golubkova T. Marketing, course - lecture notes. - Rīga: BIA,
2013. Golubkova E. Marketing communications. - M.: «Finpress». 2003.

[7] Romanov A., Panjko A.Marketing communications- M.: Eksmo, 2006.

[8] Romanenkova O. Marketing communications, - M: Jurajt, 2015.

[9] Sinevaja I., \& Zemljak S., \&Sinjaev V. Marketing communications:- M.:«Dashkov\&Co», 2005.

[10] Sillars, A.L., \& Vangelisti, A.L. Communication: Basic properties and their relevance to relationship research. In A. L. Vangelisti \& D. Perlman (Eds.). The Cambridge Handbook of Personal Relationships. New York: Cambridge University Press. 331-351, 2006.

[11] Education law (pieņemts 29.10.1998., stājies spēkā 01.06.1999.) // Latvijas Vēstnesis Nr. 343/344 (1404/1405) 17.11.1998., ar grozijumiem lïdz 16.07.2015. // Latvijas Vēstnesis Nr. 127 (5445), 02.07.2015.

[12] "Informal education" within the frameworks of the $55^{\text {th }}$ week $(25 / 09-01 / 10 / 06) 60^{\text {th }}$ anniversary of UNESCO www.unesc o.org/bpi/pdf/memobpi55_NFE_ru.pdf дата просмотра 16.11.2015.

[13] Information portal 118. Driving schools and driving courses Available:

http://www.1188.1v/\%D0\%BA\%D0\%B0\%D1\%82\%D0\%B0 $\% \mathrm{D} 0 \% \mathrm{BB} \% \mathrm{D} 0 \% \mathrm{BE} \% \mathrm{D} 0 \% \mathrm{~B} 3 / \% \mathrm{D} 0 \% 90 \% \mathrm{D} 0 \% \mathrm{~B} 2 \% \mathrm{D} 1 \% 8$ 2\%D0\%BE\%D\%88\%D0\%BA\%D0\%BE\%D0\%BB\%D1\%8 B $\% 20 \% \mathrm{D} 0 \% \mathrm{~B} 8 \% 20 \% \mathrm{D} 0 \% \mathrm{BA} \% \mathrm{D} 1 \% 83 \% \mathrm{D} 1 \% 80 \% \mathrm{D} 1 \% 81$ $\% \mathrm{D} 1 \% 8 \mathrm{~B} \% 20 \% \mathrm{D} 0 \% \mathrm{~B} 2 \% \mathrm{D} 0 \% \mathrm{BE} \% \mathrm{D} 0 \% \mathrm{~B} 6 \% \mathrm{D} 0 \% \mathrm{~B} 4 \% \mathrm{D} 0$ $\% \mathrm{~B} 5 \% \mathrm{D} 0 \% \mathrm{BD} \% \mathrm{D} 0 \% \mathrm{~B} 8 \% \mathrm{D} 1 \% 8 \mathrm{~F}$

[14] Autoprieks/Credo. http://www.credo.lv/ru/?gclid=CMT567n MtcoCFWXecgod_0wGWQ

[15] Fortūna. (2016) http://fortuna.lv/ru/aboutus

[16] The driving schools Homepage Real Proff. Available: http://www.realproff.lv/

[17] Promotion (2009). http://marketing-tut.ru/upravlenie-marketi ngom/struktura-prodvizheniya-tovara.htm

[18] Wilsteam.

(2011).http://www.wilstream.ru/communication/celevaya-au ditoriya/potrebitelskiy-marketing/ 